\title{
Primary health care attributes assessment: children and adolescents living with HIV
}

\author{
Avaliação dos atributos da atenção primária à saúde: criança e adolescente vivendo com HIV
} Evaluación de atributos de la atención primaria a la salud: niños y adolescentes viviendo con VIH

\author{
Bibiana Sales Antunes ${ }^{1}$ \\ Stela Maris de Mello Padoin ${ }^{1}$ (B) \\ Cristiane Cardoso de Paula ${ }^{1}$ (D)
}

1. Universidade Federal de Santa Maria.

Santa Maria, RS, Brasil.
Corresponding author:

Cristiane Cardoso de Paula.

E-mail: cris_depaula1@hotmail.com

Submitted on $08 / 03 / 2017$

Accepted on 03/21/2018.

DOI: 10.1590/2177-9465-EAN-2017-0233

\section{Abstract}

Objectives: To evaluate the attributes derived from Primary Health Care (PHC) focusing on children and adolescents living with HIV, in the experience of health professionals, comparing traditional units (BHU) and Family Health Strategy (FHS). Method: Cross-sectional research in which 524 professionals from 25 cities of Rio Grande do Sul, Brazil were interviewed. The Primary Care Assessment Tool Brazil was used from March through August 2014. Results: The PHC score attributed to FHS (7.8) was higher than that attributed to $\mathrm{BHU}(6.8)$. The higher scores contributed to the home visit, the professional qualification and the employment bond, the latter acting independently of the others. Conclusion: The satisfactory evaluation of the derived attributes approves the interaction with users and community and the potential of PHC to attend these children and adolescents, and the home visit qualifies the practice.

Keywords: Primary Health Care; Health Services Research; HIV; Child Health; Adolescent Health; Health Personnel.

\section{Resumo}

Objetivos: Avaliar os atributos derivados de Atenção Primária à Saúde (APS) com foco nas crianças e adolescentes vivendo com HIV, na experiência de profissionais, comparando unidades do modelo tradicional (UBS) e Estratégia Saúde da Família (ESF). Método: Pesquisa transversal em que foram entrevistados 524 profissionais de 25 municípios do Rio Grande do Sul, Brasil. Foi utilizado o instrumento PCATool-Brasil entre março-agosto de 2014. Resultados: O escore derivado atribuído às ESF foi maior $(7,8)$ do que o atribuído às UBS $(6,8)$. Contribuíram com o alto escore as variáveis: a visita domiciliar, a formação profissional e o vínculo empregatício, essa última atuando independentemente das demais. Conclusão: A avaliação dos atributos derivados demonstra a interação com os usuários e a comunidade e o potencial da APS para atender essas crianças e adolescentes, sendo que a visita domiciliar qualifica a prática.

Palavras-chave: Atenção Primária à Saúde HIV; Avaliação de Serviços de Saúde; Saúde da Criança; Saúde do Adolescente; Profissionais da Saúde.

\section{Resumen}

Objetivos: Evaluar los atributos derivados de la Atención Primaria a la salud (APS) con enfoque en niños y adolescentes que viven con VIH, en la perspectiva de los profesionales de salud, comparando las unidades de modelo tradicional (UBS) y la Estrategia de Salud de la Familia (ESF). Método: Estudio transversal. Participaron 524 profesionales de 25 municipios de Rio Grande do Sul, Brasil. Se utilizó el instrumento PCATool-Brasil, entre marzo y agosto de 2014. Resultados: La puntuación derivada de APS atribuido a $\operatorname{ESF}(7,8)$ fue mayor que la atribuida a UBS $(6,8)$. Los puntajes más altos contribuyeron a la visita domiciliaria, la calificación profesional y el vínculo laboral, este último actuando independientemente de los demás. Conclusión: La evaluación de atributos derivados demuestra la interacción con los usuarios y la comunidad y el potencial de APS para atender a estos niños y adolescentes, siendo que la visita al domicilio califica la práctica.

Palabras clave: Atención Primaria a la Salud; Investigación de Servicios de Salud; VIH; Salud del Niño; Salud del Adolescente; Profesionales de la Salud. 


\section{INTRODUCTION}

The epidemic of human immunodeficiency virus (HIV) presented modifications in it's characteristics, not only in the epidemiological profile, as well as in the evolution to health's chronic condition. Regarding health assistance, in the begining of epidemic, in the 1980s decade, the main scenery constituted itself by hospital and ambulatory services. In the face of successful actions in the management of the infection in the primary health care $(\mathrm{PHC})$ in some brazilian cities, the process of decentralization and shared management among services (specialized and primary health) was recognized as a possibility for presention and assistance to people living with HIV. ${ }^{1}$

As for epidemiological modifications, there was the inclusion of children and adolescents infected by HIV. In addition to ongoing health care, in clinical practice and social esphere, common to people living with HIV, children and adolescents have specificities due to dependence of family members. We highlight the monitoring and judicious evaluation of it's vulnerabilities. ${ }^{2}$

This population's vulnerability, in the individual plan, involves biological factors (immunity in development), clinical (AIDS symptoms), medictive (adherence to therapy, side effects, dose adaptations and therapeutic failure) and of assistance (permanent health follow-up and hospital (re)admitions). Social plan is about care dependence from another and autonomy, beyond the prejudiced answer to the epidemic and orphanage. And programatic plan refers to health services organization and qualification.

Among these vulnerabilities, there are difficulties of Access and linkage of services in PHC, specially by the fear of diagnostic confidentiality in the community and the maintenance of the assessment flow in the health system with resolution whether it is the prevention and management of infection or childcare or hebiatrics.

It is recognized that $\mathrm{PHC}$ is characterized by the access by first contat, longitudinality and assessment integratility, assessment coordination in the health system, that should be centered in family, guaranteeing orientation and participation of professional's continuity and cultural competence. When the four essential attributes are present, a service can be considered a primary care provider and, when derivative attributes are present, it can be considered to have potential for interaction with users and community. ${ }^{3}$

Among derivatives, family orientation attribute evaluates the individual need considering the family context and it's potential for care, including tools for such approach. Assistance to family happens when there is integrality and it's based on the health care of the user and his family in their environment. In the community orientation, health is recognized through epidemiology and direct contact with the community, so that, in view of the evaluation of services, it can be proposed changes in programs and monitoring their effectiveness. ${ }^{3}$
Verifying derived attributes show better health results as the bigger scores are found, minimizing vulnerabilities of the population of children and adolescents living with HIV. ${ }^{2,4,5}$ Studies of this kind are less frequent in the scientific knowledge production, ${ }^{6}$ but there is unanimity to evaluate $\mathrm{PHC}$ to identify, in a determined scenery, the degree of each health service and health team orientation, enabling scientic knowledge on it's effectiveness. $^{7,8}$

Literature study point to contributions to minimize programatic vulnerability to HIV in PHC and shows issues related to the structure and organizational dynamic of services, specially, when it considers the access, the capacity of the team and the articulation among the team and the services. Beyond these issues, difficulties in operating precocious diagnosis practices, counseling and home visits, that limit the $\mathrm{PHC}$ resulotive potentional. ${ }^{4}$ However, there are other practices that are recommended to be developed by $\mathrm{PHC}$ such as promotion and prevention of HIV infection, integrating services for precocious diagnosis and antiretroviral therapy followup. ${ }^{1}$ However, centered in a technical-instrumental dimension. ${ }^{5}$

This study aimed to evaluate derived attributes of Primary Healht Care focusing on children and adolescents living with HIV by the professional's experiences, comparing traditional model units (PHU) Family Health Strategy (FHS).

\section{METHOD}

Cross-sectional research in $\mathrm{PHC}$ services, such as FHS or PHU' traditional model, in cities where there are children and adolescents living with HIV. Approximately 47 children and 45 adolescents are followed up in an infeccious disease ambulatory, situated in the West-Centered of Rio Grande do Sul, Brazil (RS, BR). Average of $60 \%$ of these mantain residence in Santa Maria, this city's service headquarters. For data collection, were selected the cities where the children and adolescents reside, totalizing 25, which are located in the Center-east, Center-west, southwest southeast, northwest and northeast of RS/BR (Figure 1). Phone contact with Health Secretaries, with FHS and $\mathrm{PHU}$ of each city were made to forsee locomotion to them and develop interviews from march to August 2014.

Considering that in Brazil, we're in a transitional phase from the traditional model of $\mathrm{PHU}$ to $100 \%$ population coverage in the FHS model, the sample has heterogeneous distribution among cities and also, in each city. As exemples, we cite Uruguaiana, as only traditional model with $13 \mathrm{PHU}$, while the city of Santiago, there's only FHS model, other cities have both models, distributed in a heterogenous way. At the time, there was $60 \mathrm{PHU}$ and108 FHS in cities accessed for collection.

To develop the interviews, nine data collectors were trained: four master's students and five scientific initiation students. Training was done by the project coordination that also supervised field work through weekly meetings to discuss 
Figure 1. Localtion, population and and coverage by type of service of the municipalities of data collection, Rio Grande do Sul, Brazil, 2014.

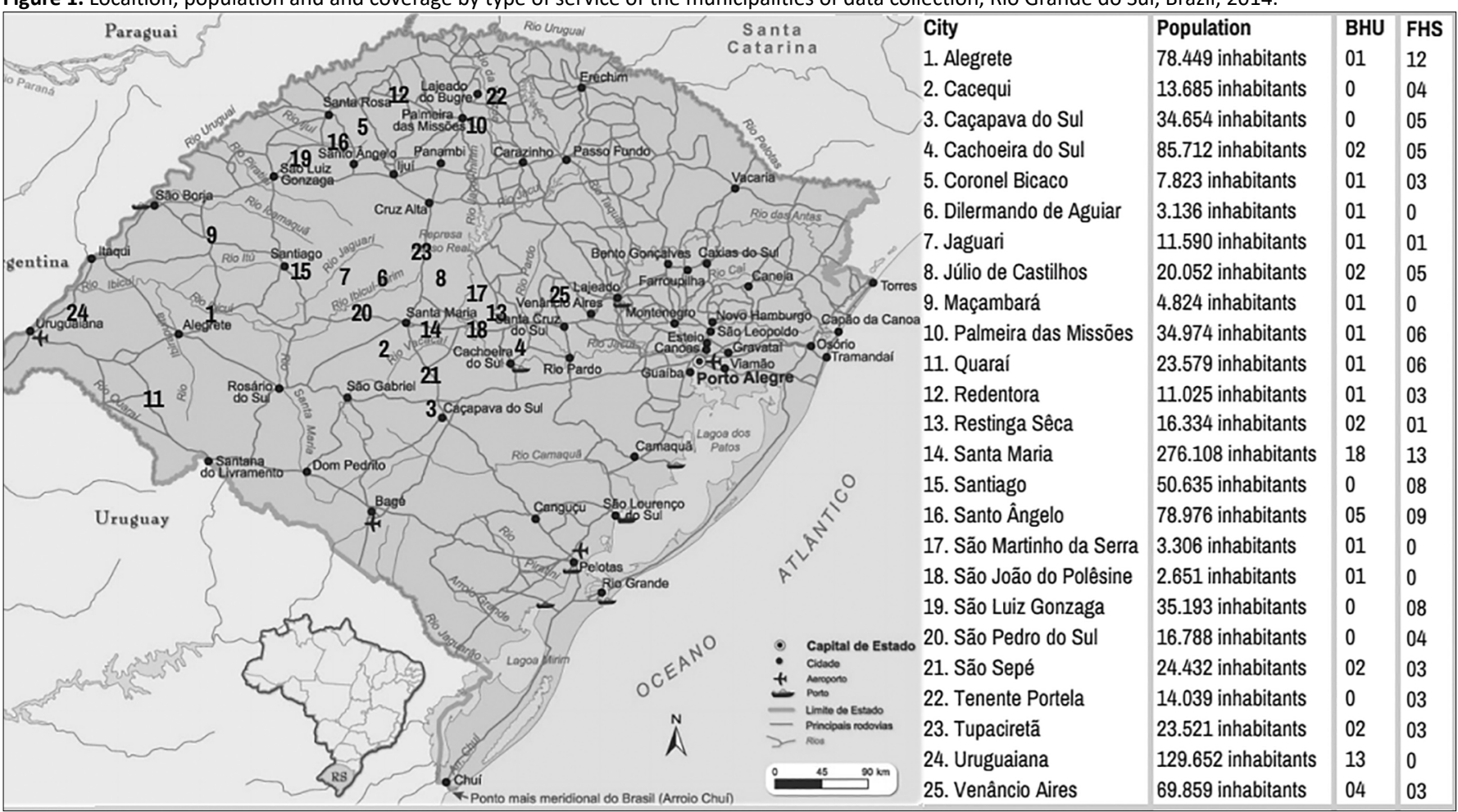

facilities and difficulties encountered. The daily journey of data collection was eight hours, as it was in line with the workload of the PHC professionals.

Elegible population for the study was $596 \mathrm{PHC}$ profissionals, being accessed the total population of referred municipalities, without sample calculation. Inclusion criteria were: graduated in Nursing, Medicine (gynecologist, pediatrician, general practitioner) or Odontology. Exclusion criteria: professionals with temporary contract (those who don't belong to effective board of the municipality), who was on vacation, attestation of health or withdrawal from work, which implied 42 professionals excluded ( $7 \%$ ). 27 profissionals ( $4.9 \%$ ) corresponded to losses, after persisting on three attempts for contact, finalizing the data collection with 527 profissionals.

On the data collection, characterization of population questionnaire was used with sociodemographic variables (age, genre); of academic training and link (training, conclusion of undergraduate, graduate studies, conclusion of graduate studies, employment and time of service); and for the possibility of assist the child and/or adolescent with HIV (even without knowing the infection diagnosis). This instrument was constracted from previous experince by the research group in concluded projects, which was submitted to pré-test, which enabled language adaptations and assortment of questions.
To evaluate quality of health assessment from the presence and extension of attributes by PHC (dependable variables), the instrument PCATool - Brazil, professional version, which is devided in eight (8) components was used. ${ }^{9}$ Among instruments that aim to evaluate quality of $\mathrm{PHC},{ }^{6}$ the Primary Care Assessment Tool (PCATool) enables to measure the presence and extention of PHC attributs in different sceneries in Brazil and abroad. ${ }^{9-11}$ Attributes are defined by an inseparable group of structural elements present in health services, denominated essential and derivatives. The first ones are: access and first contact with health services, longitudinality, coordenation and integrality. Derived attributes, which qualifies actions of services in PHC, are: family and community guidance. ${ }^{3}$

In this article, we analyzed derived attributes: Family Guidance (G1: about ideas or opinions in the process of planning treatment/ care; G2: about illnesses or health issues existing in the family; G3: willingness to meet family members to discuss health or family issues) and Community Guidance ( $\mathrm{H} 1$ : home visits; $\mathrm{H} 2$ : knowledge of community health issues; H3: service listens to opinions and ideas from the community to improve health services; $\mathrm{H} 4$ : research with users about satisfying people's needs; H5: research in community to identify health problems; $\mathrm{H} 6$ : presence of users in local Health Council). We justify this choice of derived attributes by the convergence of the object of study that is related 
to programatic vulnerability in the child's health, which indicates the need to evaluate health professionals' interaction with users and community to qualify actions of the PHC services. ${ }^{12}$

Data were inserted in the software Epi-info ${ }^{\circledR}$ version 7.0, seeking accuracy with independent double typing, being that afterwards errors and inconsistencies were verified and corrected. For analysis, the software Statistical Analysis System (SAS) version 9.3 was used. Scores were obtained by item's arithmetic mean that compose derived attributes, according to the guidance of the instrument manual for analysis. To evaluation, scores were dichotomized according values $\geq 6$. 6 for high score and $<6.6$ for low score. High score is defined as satisfatory extension of each attribute and low score as insatisfactory. ${ }^{9}$

Categoric variables were presented in absolute and relative frequency and continous variables, in average, standard deviation, minimum and maximum. For comparison of dichotomized scores proportions (high score and low score) of PHC attributes in sociodemographic profile variables, of formation and of professionals' occupational situation, Pearson's Chi-Square test was used. When PHC attributes' scores were compared, according to type of service, Mann Whitney Test was applied. For statistical analysis, significance level of $5 \%$ was adopted. For data reliability, Cronbach's Alpha was calculated, considering as consistency indicators of $p$-value $<0.70$.

For verification of associated variables from high score related to derived attributes, Poisson Regression was applied. Prevalence Reasons (PR) were estimated and confidence gap are respective (IC 95\%). In the crude and adjusted analysis, the independent variables were associated with the high score with $p$-value $<0.25$.

Ethical aspects of studies with human beings were respected with Research Ethics Committee approval from Federal University of Santa Maria, consubstanciated feedback $n^{\circ}$ $183.572 / 2013$ of the matrix project. The written informed consent form was presented in two copies, being one for the participant and another to be archived was presented in two copies, being one for the research participant and another archived copy.

\section{RESULTS AND DISCUSSION}

The researched population characterization identified 270 professionals in PHU (51\%) and 257 in FHS (49\%). As for age, most was $<30$ years old $(n=420,79.7 \%)$ and female $(n=339$, $64.4 \%)$. As for training, General Practitioner $(n=174,33 \%)$, Gynechologist $(n=38,7.2 \%)$, Pediatrician $(n=33,6.3 \%)$, Nurse $(n=167,31.7 \%)$ and Odontologist $(n=115,21.8 \%)$.

Comparison between the types of PHC services showed derived score of $\mathrm{PHC}$ attributed to FHS (7.8) was higher than the one attributed to $\mathrm{PHU}$ (6.8), both satisfatory. Result happened as expected, considering defining characteristics of FHS such as the process of territorialisation, electronic information system and community participation. When evaluated separetely, derived attributes maintained satisfatory scores in FHS, family guidance (8.4) and community (7.2). However, in PHU, only the family guidance was satisfatory (7.9). (Table 1)

FHS predominance, with higher score for derived attributes, indicates that the satisfatory presence of attributes favours and qualifies health care, result that was also encountered with other studies with professionals ${ }^{10,13-15}$ and with caregiver. ${ }^{16,17}$ This indicates PHC quality to assist children and adolescents living with HIV and their families, convergent with meaningful increase of chronic conditions and user survival with infectious contagious diseases, that modified health care demands for health services, such as users' integration, family and community. ${ }^{18}$ Transformation from the traditional assistance model from PHU to FHS aims addressing the user's needs in his/her family and community core. Through guidance and normatization of national policies to consolidate health care networks, emphasizing health promotion according social determinants and community needs. ${ }^{13,16}$

In study that presented the satisfatory score for family guidance in the FHS, family caregivers of children under one year old reported that physicians and nurses knew their families and prevalent health issues, and they believed that the health team was interested in knowing the health conditions of the community. ${ }^{17}$ On the other hand, in the experience of health professionals from the city São Luiz (Maranhão) the attribute 'family guidance' obtained low score for FHS. ${ }^{11}$ This indicates the importance to evaluate the health care in the FHS in the experience of those that care and others that seek it, comprehending different perspectives, even if they don't converge, but to complement in order to potentialize the interaction of PHC staff with users and community.

Table 1. Comparison of PHC derived attributes scores in the experience of PHC professionals from the municipalities of Rio Grande do Sul, Brazil, 2014.

\begin{tabular}{|c|c|c|c|c|c|}
\hline \multirow[t]{2}{*}{ Derived attributes } & \multicolumn{2}{|c|}{$\begin{array}{l}\text { Primary Heaalth Care Unit } \\
\quad * \text { PHU }(n=243)\end{array}$} & \multicolumn{2}{|c|}{$\begin{array}{l}\text { Family Health Strategy } \\
{ }^{*} \text { FHS }(n=249)\end{array}$} & \multirow[t]{2}{*}{ p-value* } \\
\hline & Average (DP) & Minimum-Maximum & Average (DP) & Minimum-Maximum & \\
\hline Family Guidance & $7.9(2.2)$ & $0-10$ & $8.4(1.5)$ & $3.3-10$ & 0.039 \\
\hline Community Guidance & $5.6(2.2)$ & $0-10$ & $7.2(1.5)$ & $2.2-10$ & $<0.001$ \\
\hline Derived Score & $6.8(1.7)$ & $0.6-10$ & $7.8(1.2)$ & $0.4-10$ & $<0.001$ \\
\hline
\end{tabular}

* Mann-Whitney Test; SD: standard deviation. 
In a study developed in Piracicaba (São Paulo), the evaluation of professionals also resulted in higher scores for FHS in the attributes 'family guidance' and 'community guidance', in relation with PHU scores. This attributes favour planning and developing of actions that enable qualified health care to users. ${ }^{19}$ In research developed in Chapecó (Santa Catarina) that evaluated the experiences of health professionals from PHU, scores to both attributes were satisfatory and higher in relation to other $\mathrm{PHC}$ attributes. ${ }^{20}$ In studies with users ${ }^{18,21}$ and with caregivers, ${ }^{16}$ the studies presented low score for PHC in different services. These results point to health professionals evaluate their services with qualified care according to the available resources; however users, including family caregivers, realize low human and material resources, and they refer that there isn't resolutiveness, reiterating the importance of both perspectives for the quality of $\mathrm{PHC}$, more prevalent in FHS.

Evaluation of items (questions) that compose structural elements of derived attributes enabled a better comprehension of results. Evaluation that contributed with average score of Family Guidance were professionals' questionings on existing ilnesses and family's health issues (G2) during the consultation and disposition to discuss health issues with the family (G3), being that both questions obtained satisfatory score in both services (Table 2).

In Community Guidance, only home visits $(\mathrm{H} 1)$ obtained satisfatory score. However, when compared with type of service, PHU presented low score for visits while FHS presented a high score for community opinions to increase the service (H3) (Table 2).

Studies with family caregivers of children, in both types of services and centred care of family indicated health practices still not value aspects of family members, pointing to fragility in $\mathrm{PHC} .{ }^{12,21}$ In counterpoint, the study developed in São Luiz (Maranhão), only services with FHS, pointed an exchange of information with family members to be a reality. ${ }^{11}$ Also when the focus of care is tuberculosis, there is the inclusion o family members in the therapeutic process to face the disease. ${ }^{22}$ Such results signal the need to considerate the users' participation in the formulation of proposals and actions to the effectiveness of health care.

Another factor to health care effectiveness are home visits, ${ }^{3,7}$ evaluated with high score in FHS in this article. This positive evaluation from health professionals ${ }^{11}$ converge with the evaluation of family caretakers' perspectives, ${ }^{12}$ but not always as users. ${ }^{11}$ Home visits enables health education and shares experiences with users and families. For such, professionals need a broad knowledge, beyond clinicals, to consider cultural and social aspects. Study in infectology, with users' population with tuberculosis, considers reception and informations in the perspective of visits to contribute to avoid the abandoment of treatment, amplifying therapeutic possibilities. ${ }^{23}$

The visit is linked to the ease of access, extension of equity and interpretation of the disease through the recognition of daily life. It provides direct contact with the population when it facilitate the intermediation between the home and the health service, including nurses' clinical practices. ${ }^{24,25}$ In this sense, amplified clinical, as instrumentalist of the process of health care, it minimizes the programatic vulnerability. It can contributes to the health care of children and adolescents living with HIV, when it adequates HIV management to individual and social vulnerable situations of families responsible for daily life care. Faced with the need to expand the clinical practice of nurses in the care of children and adolescents, the expanded clinic assists in the process of health work centered on users, with family and community orientation.

Beyond visits, PHC services must hear opinions from the community to qualify it fundamentally to plan actions. However, scores show that, in practice, derived attributes don't stabilish themselves as a management tool and driving force for decisionmaking, even though it obtains a higher score for FHS, which indicates that professionals of this kind of service has a better knowledge in the community they are inserted. ${ }^{26}$ The potential of the FHS for the situational diagnosis of children and adolescents with HIV within their area is then inferred, including to promote communication between services, active search and continuity of care in an integral way, from the proximity with the families of the children and recognition of their needs.

The absence of a statistically significant difference indicates that we did not find evidence strong enough to prove which of the items that make up the Family and Community Orientation interfere in the high score for each type of service evaluated (FHS and $\mathrm{PHU}$ ). Although no difference, we highlight that they may be considered meaningful from a therapeutic point of view, such as the item that asks users what they think about care/treatment planning (G1). The lack of knowledge or lack of consideration of the difficulties faced by family members in the daily care of the child, interferes negatively in the therapeutic success. Family members refer to difficulties with antiretrovirals administration, diagnosis secrecy, social support network and prejudice. ${ }^{27}$

Health services to investigate (H5) and know community's health issue $\left(\mathrm{H}_{2}\right)$ can be considered meaningful from an health care point of view, since planning actions to execution, including promoting active search and assessment continuation. However, the lack of knowledge of infected users in their area of influence negatively interferes with programmatic vulnerability. ${ }^{28}$

From obtained scores, it is observed the presence of derived attributes approaches the health professional of the users and the community and it is inferred that this potentiates the actions for the management of the infection, considering the vulnerabilities of these children and adolescents. As for social vulnerability, being close to the community, contributes to promoting actions of support and daily care developed by family members of children and by aquisition of adolescent's autonomy.

Still related to the high score, when associated to variables of formation and occupation of professionals, independently of the type of the service, only with meaningful employment relationship in gross and adjusted regression (Table 3 ). 
Table 2. Comparison of items that compose elemts of attributes 'Family Guidance' ( $N=524)$ and 'Community Guidance' $(\mathrm{N}=492)$, dicotomized in high and low score, according the type of service in experience of health professionals of municipalities from Rio Grande do Sul, Brazil, 2014.

\begin{tabular}{|c|c|c|c|c|c|c|}
\hline & \multicolumn{3}{|c|}{ Primary Health Care Unit } & \multicolumn{3}{|c|}{ Family Health Strategy } \\
\hline & $\begin{array}{l}\text { High Score } \\
\quad(\geq 6.6) \\
n(\%)\end{array}$ & $\begin{array}{l}\text { Low Score } \\
\quad(<6.6) \\
n(\%)\end{array}$ & p-value* & $\begin{array}{l}\text { High Score } \\
\quad(\geq 6.6) \\
n(\%)\end{array}$ & $\begin{array}{l}\text { Low Score } \\
\quad(<6.6) \\
n(\%)\end{array}$ & p-value* \\
\hline Family Guidance ( $N=524)$ & & $n=\mathbf{2 7 0}$ & & & $n=254$ & \\
\hline $\begin{array}{l}\text { G1 - Do you ask the patients what are their ideas and } \\
\text { opinions on planning the treatment and care of teh } \\
\text { patient and family member? }\end{array}$ & & & 0.490 & & & 0.983 \\
\hline High Score & $118(43.7)$ & $15(5.6)$ & & $91(35.8)$ & $14(5.5)$ & \\
\hline Low Score & $125(46.3)$ & $12(4.4)$ & & $129(50.8)$ & $20(7.9)$ & \\
\hline $\begin{array}{l}\text { G2 - Do you ask about illnesses and health issues that } \\
\text { may occur in patient's families? }\end{array}$ & & & 0.798 & & & 0.724 \\
\hline High Score & $159(58.9)$ & $17(6.3)$ & & $142(55.9)$ & $23(9.1)$ & \\
\hline High Score & $147(54.1)$ & $16(5.9)$ & & $159(62.6)$ & $24(9.4)$ & \\
\hline Low Score & $97(35.9)$ & $11(4.1)$ & & $61(24.0)$ & $10(3.9)$ & \\
\hline Family Guidance General Score & $243(90.0)$ & $27(10.0)$ & $<0.001$ & $220(86.6)$ & $34(13.4)$ & $<0.001$ \\
\hline Community Guidance ( $N=492$ ) & & $\mathrm{N}=\mathbf{2 4 8}$ & & & $\mathrm{N}=\mathbf{2 4 4}$ & \\
\hline $\begin{array}{l}\text { H1 - Do you or anybody from your service do home } \\
\text { visits? }\end{array}$ & & & 0.433 & & & 0.714 \\
\hline High score & $60(24.2)$ & $47(18.9)$ & & $140(57.4)$ & $93(38.1)$ & \\
\hline Low Score & $72(29.0)$ & $69(27.8)$ & & $6(2.5)$ & $5(2.0)$ & \\
\hline $\begin{array}{l}\mathrm{H} 2 \text { - Do you believe that your health serice have } \\
\text { adequate knowledge of the health issues in the } \\
\text { community they asses? }\end{array}$ & & & 0.823 & & & 0.157 \\
\hline High score & $40(16.1)$ & $45(18.10$ & & 73 (29.9) & $59(24.2)$ & \\
\hline Low score & $92(37.1)$ & $71(28.60)$ & & 73 (29.9) & $39(16.0)$ & \\
\hline $\begin{array}{l}\text { H4 - Do you do research with patients to see if services } \\
\text { are satisfying (assessing) people's needs? }\end{array}$ & & & 0.336 & & & 0.691 \\
\hline High score & $16(6.4)$ & $19(7.7)$ & & $34(13.9)$ & $25(10.2)$ & \\
\hline Low score & $116(46.8)$ & $97(39.1)$ & & $112(45.9)$ & 73 (29.9) & \\
\hline $\begin{array}{l}\text { H5 - Do you research in the community to identify } \\
\text { health issues you should know? }\end{array}$ & & & 0.597 & & & 0.363 \\
\hline High score & $14(5.6)$ & $10(4.0)$ & & $30(12.3)$ & $25(10.2)$ & \\
\hline Low score & $118(47.6)$ & $106(42.7)$ & & $116(47.5)$ & 73 (29.9) & \\
\hline $\begin{array}{l}\text { H6 - Presence of Users in Local Health Council } \\
\text { (Board of Directors, User Council) }\end{array}$ & & & 0.327 & & & 0.839 \\
\hline High Score & $44(17.7)$ & 32 (12.9) & & $60(24.6)$ & $39(16.0)$ & \\
\hline Low Score & $88(35.5)$ & 84 (33.9) & & $86(35.2)$ & $59(24.2)$ & \\
\hline Community Guidance Score & $132(53.2)$ & $116(46.8)$ & 0.309 & $146(59.8)$ & $98(40.2)$ & 0.002 \\
\hline
\end{tabular}

* Person's Chi-Square Test. 
The study who associated derived attributes with professionals' profile wasn't localized, thus it is not possible to identify convergences or divergences with investigations that used PCATool, being a differential in this study. We infere that statutory relationship can be related to low rotativity of $\mathrm{PHC}$ services and qualified training. Although training didn't obtain statistical meaningfulness, on gross regression, nurse's participation on high score can be related to his/her training directed to family and community aspects. This meaningfulness didn't maintain itself on adjusted regression, which can be influenced by other variables such as link. This study points the impact of stable employment relationship in the quality of care, which indicates the need to provide human resources in $\mathrm{PHC}$, specially in $\mathrm{FHS}$, as one of the challenges to amplifying the coverage.

It should be noted that the results were interpreted with some limitations, since they pointed out the professionals' view, indicating the possibility of expansion when evaluating the experience, also, of users and managers. However, the lack of national PHC studies focusing on HIV points to the relevance of similar assessments.

Table 3. Poisson gross and adjusted regression for independent variables associated to high score of PHC in relation to derived attributes in evaluation of health care assessment of children and adolescents with HIV, in the health professionals' experience in municipalities of Rio Grande do Sul, Brazil, 2014.

High Score

Variables
RPb*
IC95\%†
p-value RPa
IC95\%† Minimum-Maximum p-value

Employment relationship

\begin{tabular}{lcccccc} 
Statutory & 0.881 & $0.808-0.960$ & $\mathbf{0 . 0 0 4}$ & 0.869 & $0.815-0.925$ & $<0.001$ \\
Clerk & 0.937 & $0.856-1.025$ & 0.156 & 0.891 & $0.826-0.962$ & $\mathbf{0 . 0 0 3}$ \\
Outsourced & ref & & & ref & & \\
\hline
\end{tabular}

\section{Time of service}

\begin{tabular}{|c|c|c|c|c|c|c|}
\hline$\leq 3$ years & 1.013 & $0.9670-1.0610$ & 0.5790 & 1.0160 & $0.9520-1.0830$ & 0.6380 \\
\hline$>3$ years & ref & & & ref & & \\
\hline \multicolumn{7}{|l|}{ Training } \\
\hline General pratictioner & 0.990 & $0.909-1.077$ & 0.807 & 0.972 & $0.885-1.068$ & 0.558 \\
\hline Nurse & 0.907 & $0.83-0.992$ & 0.033 & 0.920 & $0.818-1.034$ & 0.163 \\
\hline Odontologist & 0.956 & $0.872-1.047$ & 0.331 & 0.958 & $0.849-1.080$ & 0.481 \\
\hline Gynecologist & 0.943 & $0.84-1.058$ & 0.317 & 0.935 & $0.832-1.050$ & 0.257 \\
\hline Pediatrician & ref & & & ref & & \\
\hline \multicolumn{7}{|l|}{ Undergraduation } \\
\hline$\leq 15$ years & 0.980 & $0.936-1.026$ & 0.386 & 1.015 & $0.940-1.097$ & 0.698 \\
\hline$>15$ years & ref & & & ref & & \\
\hline \multicolumn{7}{|l|}{ Graduate Studies } \\
\hline Specialization & 1.081 & $0.929-1.258$ & 0.314 & 1.080 & $0.926-1.260$ & 0.329 \\
\hline None & 1.154 & $0.991-1.344$ & 0.660 & 0.981 & $0.629-1.531$ & 0.932 \\
\hline Resídency & 1.130 & $0.967-1.320$ & 0.123 & 1.099 & $0.930-1.298$ & 0.267 \\
\hline Master's & ref & & & ref & & \\
\hline \multicolumn{7}{|l|}{ Graduate Studies } \\
\hline$\leq 6$ years & 0.973 & $0.920-1.029$ & 0.333 & 0.979 & $0.906-1.057$ & 0.585 \\
\hline$>6$ years & ref & & & ref & & \\
\hline
\end{tabular}

* RPb: Gross Poisson Regression; † IC 95\%: Confidence gap of 95\%; ‡ RPa: Poisson regression adjusted by: Age, Conjugal Situation, Employment Bond, Length of Service, Formation, Completion of Undergraduation, Gradute Studies, and Graduate studies Completion. ref: Value of reference. 


\section{CONCLUSION}

Both services present satisfatory score in the $\mathrm{PHC}$ derived attributes, which indicates potential of these services for the attention of children and adolescents living with HIV. Their differences were safe in that the PHC-derived score attributed to the FHS was higher than that attributed to the PHU. Associated with the high score were the professional qualification and the employment relationship. Only the item related to the home visit was significantly satisfactory in the community orientation attribute. Even items with no statistical significance were important for indicating the need for greater interaction between $\mathrm{PHC}$ professionals and children and adolescents living with HIV, including their caregivers.

We recomment that in planning of actions in health professionals consider the opinion of users and their families electing priorities in the family and community core, from their needs. And, that consider home visits a tool to qualify actions and obtain effectiveness in health care. We conclude that the expansion of FHS coverage in municipalities may qualify $\mathrm{PHC}$.

\section{AKNOWLEDGEMENTS}

To the professor Doctor Luis Felipe Dias Lopes, for the support for statistical analysis.

\section{Financing}

Research Program for SUS and Foundation for Research Support of the State of Rio Grande do Sul (PPSUS/ FAPERGS-2013-2014): Process number: 1217-2551/13-0; National Council for Scientific and Technological Development (CNPq) - Universal Funding (2013-2016): Process number: 482554/2013-4; Productivity in Research - PQ2014. Process number: 307350/2014-2.

\section{REFERENCES}

1. Ministério da Saúde (BR). Secretaria de Vigilância em Saúde. Caderno de Boas Práticas em HIV/AIDS na Atenção Básica. Brasília (DF): Ministério da Saúde; 2014.

2. Bubadué RM, Paula CC, Carnevale F, Marín SCO, Brum CN, Padoin SMM. Vulnerabilidade ao adoecimento de crianças com HIV/AIDS em transição da infância para a adolescência. Esc Anna Nery [Internet]. 2013 Sep/Dec; [cited 2017 Aug 1]; 17(4):705-12. Available from: http:// dx.doi.org/10.5935/1414-8145.20130015

3. Starfield B. Primary Care: balancing health needs: services and technology. Brasília: UNESCO, Ministério da Saúde; 2002.

4. Silva JAS, do Val LF, Nichiata LYI. A Estratégia saúde da família e a vulnerabilidade programática na atenção ao HIV/AIDS: uma revisão da literatura. Mundo da Saúde [Internet]. 2010; [cited 2017 Aug 1]; 34(1):103-8. Available from: https://www.saocamilo-sp.br/pdf/ mundo_saude/74/14_revisao_estrategia.pdf

5. Sousa ASO, Silva AL. O cuidado a pessoas com HIV/aids na perspectiva de profissionais de saúde. Rev Esc Enferm USP [Internet]. 2013 Aug; [cited 2015 Sep 15]; 47(4):907-14. Available from: http:// www.scielo.br/pdf/reeusp/v47n4/0080-6234-reeusp-47-4-0907.pdf
6. Fracolli LA, Gomes MFP, Nabão FRZ, Santos MS, Capellini VK, Almeida AAC. Instrumentos de Avaliação da Atenção Primária à Saúde: revisão de literatura e metassíntese. Ciênc Saúde Coletiva [Internet]. 2014 Dec; [cited 2015 Dec 1]; 19(12):4851-60. Available from: http://www.scielo. $\mathrm{br} / \mathrm{pdf} / \mathrm{csc} / \mathrm{v19n12/pt} 1413-8123-\mathrm{csc}-19-12-04851 . p d f$

7. Castro RCL, Knauth DR, Harzheim E, Duncan BB. Avaliação da qualidade da atenção primária pelos profissionais de saúde: comparação entre diferentes tipos de serviços. Cad Saúde Pública [Internet]. 2012 Sep; [cited 2016 Jan 3]; 28(9):1772-84. Available from: http://www.scielo.br/pdf/csp/v28n9/v28n9a15.pdf

8. Alencar MN, Coimbra LC, Morais APP, Silva AAM, Pinheiro SRA, Queiroz RCS. Avaliação do enfoque familiar e orientação para a comunidade na Estratégia Saúde da Família. Ciênc Saúde Coletiva [Internet]. 2014 Feb [cited 2017 Aug 1]; 19(2):353-64. Available from: http://dx.doi.org/10.1590/1413-81232014192.08522012

9. Hauser L, Castro RCL, Vigo A, Trindade TG, Gonçalves MR, Stein AT, et al. Tradução, adaptação, validade e medidas de fidedignidade do Instrumento de Avaliação da Atenção Primária à Saúde (PCATool) no Brazil: versão profissionais de saúde. Rev Bras Med Fam Comunidade [Internet]. Oct/Dec; [cited 2017 Aug 1]; 8(29):244-55. Available from: http://www.lume.ufrgs.br/handle/10183/140059

10. Mash R, Almeida M, Wong WCW, Kumar R, von Pressentin KB. The roles and traininf of primary care doctors: China, India, Brazil and South Africa. Hum Resour Health [Internet]. 2015 Dec; [cited 2017 Mar 1]; 13:93. Available from: https://www.ncbi.nlm.nih.gov/pmc/articles/ PMC4670546/pdf/12960_2015_Article_90.pdf

11. Bresick G, Sayed AR, Grande CL, Bhagwan S, Manga N. Adaptation and cross-cultural validation of the United States Primary Care Assessment Tool (expanded version) for use in South Africa. Afr J Prim Health Care Fam Med [Internet]. 2015 Jun; [cited 2017 Mar 1]; 7(1):e1-e11. Available from: https://www.ncbi.nlm.nih.gov/pubmed/?t erm=Adaptation+and+cross-cultural+validation+of+the+United+State s+Primary+Care+Assessment+Tool+(expanded+version)+for+use+in + South+Africa

12. Araújo JP, Viera CS, Toso BRGO, Collet N, Nassar PO. Avaliação dos atributos de orientação familiar e comunitária na saúde da criança Acta Paul Enferm [Internet]. 2014 Sep/Oct; [cited 2016 Aug 10] 27(5):440-6. Available from: http://www.scielo.br/scielo.php?script=sci arttext\&pid=S0103-21002014000500009\&lang=pt

13. Rodríguez-Villamizar LA, Acosta-Ramírez N, Ruiz-Rodríguez M Evaluación del desempeño de servicios de atención primaria em salude: experiencia em municípios rurales em Santander, Colombia. Rev Salud Pública [Internet]. 2013 Mar/Apr; [cited 2017 Aug 1]; 15(2):167-79. Available from: http://www.scielo.org.co/scielo. php?script=sci_arttext\&pid=S0124-00642013000200001

14. Chomatas E, Vigo A, Marty I, Hauser L, Harzheim E. Avaliação da presença e extensão dos atributos da atenção primária em Curitiba Rev Bras Med Fam Comunidade [Internet]. 2013 Oct/Dec; [cited 2016 Jan 10]; 8(29):294-303. Available from: https://rbmfc.org.br/rbmfc/ article/view/828

15. Lima EFA, Sousa AI, Leite FMC, Nascimento MH, Primo CC. Avaliação da Estratégia Saúde da Família na Perspectiva dos profissionais de saúde. Esc Anna Nery [Internet]. 2016 Apr/Jun; [cited 2017 Aug 1]; 20(2):275-80. Available from: http://www.scielo.br/scielo. php?script=sci_arttext\&pid=S1414-81452016000200275

16. Leão CDA, Caldeira AP, Oliveira MMC. Atributos da atenção primária na assistência à saúde da criança: avaliação dos cuidadores. Rev Bras Saúde Mater Infant [Internet]. 2011 Jul/Sep; [cited 2016 Jan 10]; 11(3):323-34. Available from: http://www.scielo.br/scielo. php?script=sci_arttext\&pid=S1519-38292011000300013

17. Furtado MCC, Braz JC, Pina JC, Mello DF, Lima RAG. A avaliação da atenção à saúde de crianças com menos de um ano de idade na Atenção Primária. Rev Latino Am Enferm [Internet]. 2013 Mar/Apr; [cited 2016 Jan 12]; 21(2):1-8. Available from: http://www.scielo.br/pdf/rlae/ v21n2/pt_0104-1169-rlae-21-02-0554.pdf 
18. Lima EFA, Sousa Al, Primo CC, Leite FMC, Lima CDL, Maciel ELN. Avaliação dos atributos da atenção primária na perspectiva das usuárias que vivenciam o cuidado. Rev Latino Am Enferm [Internet]. 2015 May/ Jun; [cited 2016 Feb 3]; 23(3):553-9. Available from: http://www.scielo. $\mathrm{br} / \mathrm{pdf} / \mathrm{rlae} / \mathrm{v} 23 \mathrm{n} 3 / \mathrm{pt} \_0104-1169-$ rlae-0496-2587.pdf

19. Cesar MC, Campos GWS, Montebelo MIL, Sarmento G. Avaliação da atenção primária no município de Piracicaba, SP, Brasil. Saúde Debate [Internet]. 2014 Oct; [cited 2017 Aug 1]; 38(no.esp):296306. Available from: http://www.scielo.br/scielo.php?pid=S010311042014000600296\&script=sci_abstract\&tlng=pt

20. Vitoria AM, Harzheim E, Takeda SP, Hauser L. Avaliação dos atributos da atenção primária à saúde em Chapecó, Brasil. Rev Bras Med Fam Comunidade [Internet]. 2013 Oct/Dec; [cited 2015 Sep 15]; 8(29):28593. Available from: https://rbmfc.org.br/rbmfc/article/view/832

21. Pereira MJB, Abrahão-Curvo P, Fortuna CM, Coutinho SS, Queluz $\mathrm{MC}$, Campos LVO, et al. Avaliação das características organizacionais e de desempenho de uma unidade de atenção básica à saúde. Rev Gaúcha Enferm [Internet]. 2011 Mar; [cited 2016 Nov 6]; 32(1):48-55. Available from: http://www.scielo.br/scielo.php?script=sci_arttext\&pid $=$ S1983-14472011000100006

22. Nogueira JA, Trigueiro DRSG, Sá LD, Silva CA, Oliveira LCS, Villa TCS, et al. Enfoque familiar e orientação para a comunidade no controle de tuberculose. Rev Bras Epidemiol [Internet]. 2011 Jun; [cited 2017 Aug 1]; 14(2):207-16. Available from: http://dx.doi.org/10.1590/S1415$790 \times 2011000200003$
23. Clementino FS, Miranda FAN. Tuberculose: acolhimento e informação na perspectiva da visita domiciliária. Rev Enferm UERJ [Internet]. 2015 May/Jun; [cited 2017 Aug 1]; 23(3):350-4. Available from: http://www.epublicacoes.uerj.br/index.php/enfermagemuerj/article/view/4289

24. Matumoto S, Fortuna CM, Kawata LS, Mishima MS, Pereira MJB. A prática clínica do enfermeiro na atenção básica: um processo em construção. Rev Latino Am Enferm [Internet]. 2011 Jan/feb; [cited 2015 Sep 15]; 19(1):123-30. Available from: http://www.scielo.br/scielo. php?pid=S0104-11692011000100017\&script=sci_arttext\&tIng=pt

25. Tschudy MM, Platt RE, Serwint JR. Extending the Medical Home Into the Community: A Newborn Home Visitation Program for Pediatric Residents. Acad Pediatr [Internet]. 2013 Sep/Oct; [cited 2017 Aug 1] 13(5):443-50. Available from: http://www.academicpedsjnl.net/article/ S1876-2859(13)00101-0/pdf

26. Lavras $\mathrm{C}$. Atenção primária à saúde e a organização de redes regionais de atenção à saúde no Brazil. Saúde Soc [Internet]. 2011 Oct/Dec; [cited 2017 Aug 1]; 20(4):867-74. Available from: http://dx.doi.org/10.1590/ S0104-12902011000400005

27. Pacheco BP, Gomes GC, Xavier DM, Nobre CMG, Aquino DR. Dificuldades e facilidades da família para cuidar a criança com HIV/ Aids. Esc Anna Nery [Internet]. 2016 Apr/Jun; [cited 2018 Feb 2]; 20(2):378-83. Available from: http://www.scielo.br/pdf/ean/v20n2/14148145-ean-20-02-0378.pdf

28. Silva CB, Paula CC, Lopes LFD, Harzheim E, Magnago TSBS, Schimith $M D$. Health care for children and adolescents with HIV: a comparison of services. Rev Bras Enferm [Internet]. 2016 May/Jun; [cited 2018 Feb 2]; 69(3):522-31. Available from: http://dx.doi.org/10.1590/00347167.2016690315

a Derived from the master's thesis: Family and community orientation of primary health care of the municipalities of origin of children and adolescents living with HIV linked to a specialized service. Post-graduate Program in Nursing, Federal University of Santa Maria, defended in 2015. 